Article

\title{
Predicting Geographic Distribution of Forensically Significant Blow Flies of Subfamily Chrysomyinae (Diptera: Calliphoridae) in Northern Thailand
}

\author{
Tunwadee Klong-klaew ${ }^{1}$, Ratchadawan Ngoen-klan ${ }^{2}$, Kittikhun Moophayak ${ }^{3}$, \\ Kom Sukontason ${ }^{1}$, Kim N. Irvine ${ }^{4}$, Jeffery K. Tomberlin ${ }^{5}{ }^{(0)}$, Pradya Somboon ${ }^{1}$, \\ Theeraphap Chareonviriyaphap ${ }^{2}$, Hiromu Kurahashi ${ }^{6}$ and Kabkaew L. Sukontason ${ }^{1, *}$ \\ 1 Department of Parasitology, Faculty of Medicine, Chiang Mai University, Chiang Mai 50200, Thailand; \\ somtunwa@gmail.com (T.K.); kom.s@cmu.ac.th (K.S.); pradya.somboon@cmu.ac.th (P.S.) \\ 2 Department of Entomology, Faculty of Agriculture, Kasetsart University, Bangkok 10900, Thailand; \\ ngernklun@yahoo.com (R.N.); faasthc@ku.ac.th (T.C.) \\ 3 Nakhonsawan Campus, Mahidol University, Nakhonsawan 60130, Thailand; khun_khithop@hotmail.com \\ 4 National Institute of Education, Nanyang Technological University, 50 Nanyang Avenue, \\ Singapore 639798, Singapore; kim.irvine@nie.edu.sg \\ 5 Department of Entomology, Texas A\&M University, 2475 TAMU, College Station, TX 77843, USA; \\ jktomberlin@tamu.edu \\ 6 Department of Medical Entomology, National Institute of Infectious Diseases, Tokyo 162-8640, Japan; \\ MLB15110@nifty.com \\ * Correspondence: kabkaew.s@cmu.ac.th
}

Received: 11 July 2018; Accepted: 17 August 2018; Published: 21 August 2018

\begin{abstract}
Blow flies (Diptera: Calliphoridae) are carrion-breeding flies that are commonly used as evidence in forensic investigation. An adequate knowledge of ecological and geographical data of blow fly has a direct application in forensic science, as far as estimating time of colonization or corpse relocation. The aim of this study was to evaluate the occurrence of four species of Chrysomyinae (Chrysomya pinguis, Chrysomya chani, Chrysomya villeneuvi, and Ceylonomyia nigripes) across six land use types in central Chiang Mai, northern Thailand. Eighteen study sites were selected for sampling across three districts of Chiang Mai province (Mueang Chiang Mai, Mae Rim, and Hang Dong). Adult flies were collected every two weeks using a funnel trap baited with 1-day tainted beef offal. The predicted geographic distributions of forensically important blow fly species were modeled using the computer program ArcGIS, based on selected climatic variables (temperature, relative humidity, and light intensity) recorded at study sites. During the study period, 1298 adult flies were collected, with peak fly occurrence during summer (April-May). Seasonal fluctuation patterns varied depending on fly species. Climatic factors displayed diverse impact on associated fly populations. Identified species were restricted mainly to mixed deciduous forests (MDF) especially in the mountainous area. None of these flies were trapped in an urban area.
\end{abstract}

Keywords: spatial distribution; predictive distribution; GIS; forensic entomology

\section{Introduction}

Many blow flies (Diptera: Calliphoridae) species are carrion-breeding and have veterinary, medical, and forensic importance [1,2]. They play a prominent role as vectors of human as well as livestock, pathogens [1,2]. Additionally, they are currently the most commonly used arthropod group in forensic entomology research to determine time of colonization as related to the post-mortem interval $\left(\mathrm{PMI}_{\mathrm{min}}\right)$ as they are commonly associated with decomposing human remains [3,4]. The presence and abundance 
of such species are useful for reconstructing crime scenes, as particular carrion-associated species have different environmental requirements, therefore they colonize carcasses in different habitats [5].

In Thailand, the vast majority of forensic important species investigations have been focused on species identification [6-8], developmental rate of immature stage [9,10], and insect succession [11,12]. Furthermore, fly surveys have been conducted on a local scale or limited to only specific land use types, for instance, in forest or in mountainous area $[13,14]$. Knowledge about the spatial and temporal distributions is still lacking. There is very little literature on the geographic distribution of forensically important flies in Thailand, and published studies focused on the common species (e.g., C. megacephala, C. rufifacies, and M. domestica) $[15,16]$.

The objective of this study was to evaluate the occurrence of Chrysomyinae (Diptera: Calliphoridae) across a variety of land use types in central Chiang Mai, northern Thailand. Four species of blow fly in the subfamily Chrysomyinae were chosen because they are among the most prominent groups of insects associated with corpses and carrion, and are therefore important forensic indicators. Furthermore, they have been reported from human corpses in many countries [17-20]. To utilize these flies as evidence in forensic investigations, one needs to know where they occur. Blow flies are ectotherms, temperature heavily influences their development, behavior, and physiology [21]. But the influence of temperature and other climatic factors (relative humidity and light intensity) on their geographic distribution is unknown. In this study, the relationship of fly abundance with climatic factors was studied. Maps of predicted distributions for four species of carrion-associated Chrysomyinae were constructed using ArcGIS program.

\section{Materials and Methods}

\subsection{Study Areas}

This study was conducted in three districts: Urban Mueang Chiang Mai (MU), suburban Hang Dong (HD), and Mae Rim (MR) in the central part of Chiang Mai province (Figure 1). The entire area of each of the three districts was stratified initially based on a systematic random sampling method [22]. The contour maps of Chiang Mai province (MapMagic ${ }^{\mathrm{TM}}$ scale 1:150,000 with a UTM projection type, Everest Spheroid and the Indian 1975 Datum) were used for plotting the study area. The description of study sites selection and land use categories was provided in the previous study [16]. Six different land uses were classified: disturbed mixed deciduous forest (DDF), mixed deciduous forest (MDF), mixed orchard (MO), paddy field (PF), lowland village (LLV), and city town (CT) [15,16].

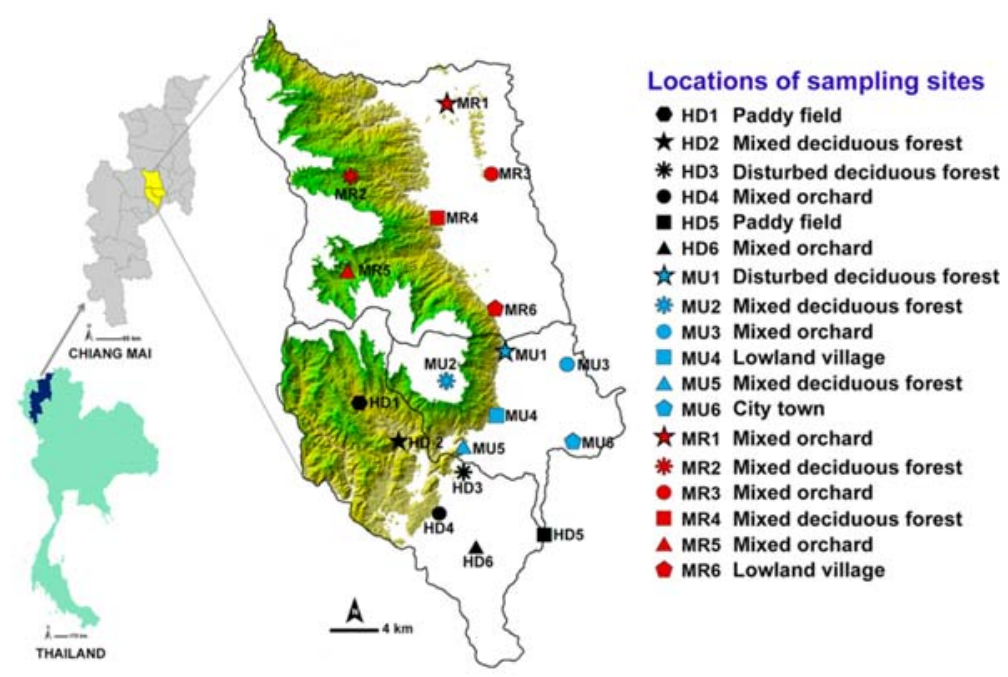

Figure 1. Map of Thailand showing three sample districts (Mueang Chiang Mai, MU; Mae Rim, MR; and Hang Dong, HD) and 18 sampling locations. Green shade represents a mountainous area. 


\subsection{Fly Collection}

Sampling was conducted at 18 sites, representing six land uses and covers three districts of the central part of Chiang Mai province, Thailand [16]. The collection was performed from May 2009 to May 2010. Adult fly collection was carried out every two weeks using an in-house prototype reconstructable funnel trap kit. The collection procedure and description of the trap was described previously $[15,16]$. Two hundred and fifty grams of 1-day tainted beef offal [23] was used as bait positioned underneath the fly entrance module at the base of trap. The traps were exposed for a 1-h period between 9:00 and 12:00 am. The physical variables were noted at each study site, including temperature $\left({ }^{\circ} \mathrm{C}\right)$, relative humidity $(\%)$ (Digital Hygro-Thermo Meter (DHT-1); (Daeyoon Scale Industrial Co., Ltd., Seoul, South Korea) and light intensity (lux) (LUX/FC light meter TM-204 Tenmars, Tenmars Electronics Co., Ltd., Taipei, Taiwan). The GPS coordinates were recorded using Garmin ${ }^{\mathrm{TM}}$ eTrex Handheld GPS (Garmin China Co., Ltd., Chaoyang, China).

All trapped flies were sacrificed using a freezer set at $0{ }^{\circ} \mathrm{C}$ for $2 \mathrm{~h}$. They were identified individually under a dissecting microscope (model SZ2-ILST, Olympus Corporation, Tokyo, Japan) using taxonomic keys of Tumrasvin et al. [24], sexed and counted at the laboratory of the Department of Parasitology, Faculty of Medicine, Chiang Mai University. Four species of Chrysomyinae flies were studied, comprising: Chrysomya pinguis (Walker), Chrysomya chani Kurahashi, Chrysomya villeneuvi Patton, Ceylonomyia nigripes (Aubertin). The adults of these species are metallic green in coloration, presenting setulae on the posterodorsal surface of stem-vein of wings. Prealar knobs bear erect hairs. The adult of Cey. nigripes is a small size blow fly $(4.0-6.0 \mathrm{~mm}$ body size). It has white mesothoracic spiracles. Eyes are dichoptic in both sexes. An orientation of sternopleural bristles is formed as $0+1$ pattern. The adults of $C$. villeneuvi, $C$. chani and C. pinguis have fuscous gena and brown to black mesothoracic spiracles. Femora are greatly swollen in $C$. villeneuvi and the disc of the 5 th tergite of males is covered with dense short hairs but almost bare in female. In C. chani and C. pinguis, the disc of the 5 th tergite is covered with many fine erect bristles in both sexes. The adult of $C$. chani has a white anterior half, with yellowish-white margin, of upper squama. On the contrary, in C. pinguis, an anterior half of upper squama is covered with dark brown to black hairs.

\subsection{Statistical Analysis}

For the statistical and geospatial analyses, a base-10 logarithm $\left(\log _{10}\right)$ transformation of the raw data $(n+1)$ was applied to improve the normality of distribution. Bivariate correlation analysis and Pearson Product Moment Correlation ( $r$ ) were analyzed to measure the association between climatic variables (temperature, relative humidity and light intensity) and fly populations. The data for all study sites were combined before analysis. One-way analysis of variance (ANOVA) followed by a post-hoc Bonferroni test (homogeneity of variance: $p>0.05$ ) or Dunnett T3 test (homogeneity of variance: $p<0.05$ ) were employed to compare mean total number of flies between land use types using SPSS 22.0 (IBM Corp., Armonk, NY, USA) for Windows $(\alpha=0.05)$. When the significant relationships were found, the kriging/co-kriging techniques were used to model spatial patterns of flies in the different localities using the Geostatistical Analyst tool of ArcGIS 9.2 program (ESRI, Redlands, CA, USA). These techniques help to predict values at unsampled locations [16]. In this study, the parameters were used in co-kriging including climatic factors that had a significant relationship with fly numbers and the total number of flies collected during May 2009 to May 2010. Furthermore, the "land use" categories were also included in the analysis as dummy variables. The mathematical model, which provided the lowest root-mean-square prediction error, was chosen as a model for estimating the semivariogram/covariance function [16].

\section{Results}

A total of 1298 Chrysomyinae flies were collected, comprising four species: C. pinguis, C. chani, C. villeneuvi, and Cey. nigripes. The most abundant fly was C. pinguis $(n=512 ; 39.4 \%)$, followed by C. chani $(n=348 ; 26.8 \%)$, C. villeneuvi $(n=245 ; 18.9 \%)$, and Cey. nigripes $(n=193 ; 14.9 \%)$. These species 
were collected mostly in MDF (75.6\%), followed by MO (11.5\%), PF (10.9\%), LLV (1.4\%) and DDF (0.7\%) (Table 1). None of these flies were trapped in CT throughout a one-year survey. Seasonal fluctuations of collected flies were found, with a peak in the summer (late April-May). The reduction of trapped specimens was observed in the rainy season and remained constantly low through the winter (Figure 2).

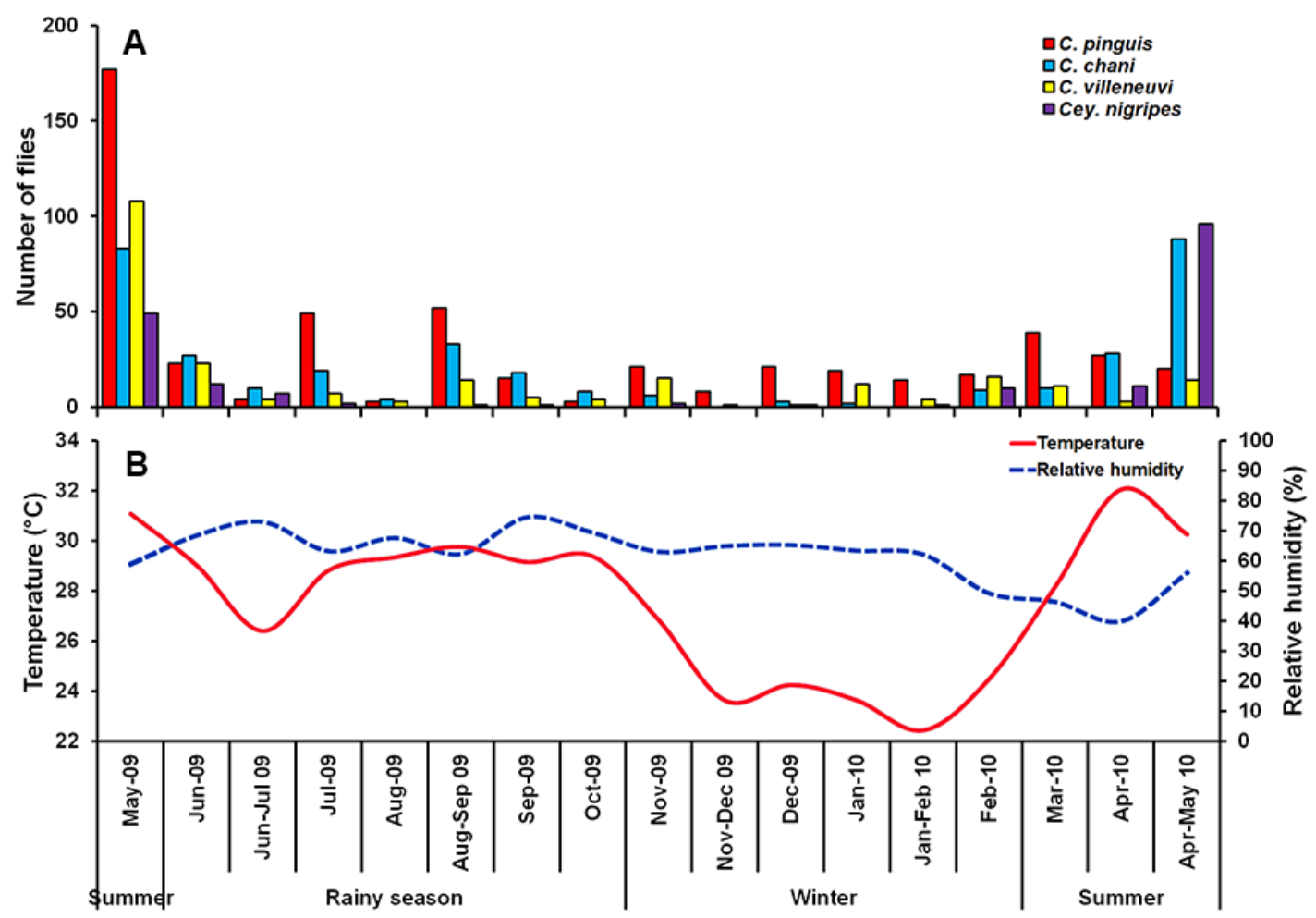

Figure 2. Monthly fluctuations in population density of C. pinguis, C. chani, C. villeneuvi, and Cey. nigripes determined using a reconstructable funnel trap baited with 1-day tainted beef offal in Chiang Mai province, northern Thailand, May 2009 to May 2010 (A), and Annual variation of temperature and relative humidity recorded during the fly survey (B).

Chrysomya pinguis exhibited a preference for MDF. No flies were collected in DDF and CT (Table 2). The abundance of flies was weak negatively correlated with light intensity $(r=-0.319, p=0.0001)$ and temperature $(r=-0.232, p=0.0001)$, but showed no correlation with humidity $(r=0.051, p=0.374)$ (Table 3). High number of this species was collected at $20-25{ }^{\circ} \mathrm{C}$ and $40-50 \% \mathrm{RH}$ (Figure 3). Co-krigged prediction maps were produced using fly population data, land uses, temperature, and light intensity. This species can probably be found predominantly in MDF at high altitude (MU2; $950 \mathrm{~m}$ asl.). The seasonal maps also showed a similar pattern to a year-survey map (Figure 4). 
Table 1. Climatic factors (temperature, relative humidity, and light intensity) recorded and total numbers of Chrysomyinae flies collected at each land use types.

\begin{tabular}{|c|c|c|c|c|c|c|c|c|}
\hline \multirow{2}{*}{ Land Uses } & \multicolumn{3}{|c|}{ Climatic Factors Recorded * } & \multicolumn{5}{|c|}{ Number of Chrysomyinae Flies Collected } \\
\hline & Temperature $\left({ }^{\circ} \mathrm{C}\right)$ & Relative Humidity (\%) & Light Intensity (Lux) & C. pinguis & C. chani & C. villeneuvi & Cey. nigripes & Total \\
\hline mixed deciduous forest & $26.5(16.7-39.8)$ & $67.0(35-87)$ & $26,550(193-107,500)$ & 417 & 282 & 163 & 119 & 981 \\
\hline $\begin{array}{l}\text { disturbed mixed } \\
\text { deciduous forest }\end{array}$ & $28.4(21.0-39.3)$ & $61.5(35-80)$ & $59,403(2320-359,600)$ & 0 & 2 & 2 & 5 & 9 \\
\hline mixed orchard & $28.4(19.7-45.2)$ & $59.0(25-89)$ & $47,200(1000-118,500)$ & 83 & 18 & 27 & 21 & 149 \\
\hline paddy field & $27.5(19.6-40.8)$ & $63.5(39-83)$ & $36,300(6700-112,000)$ & 11 & 44 & 44 & 42 & 141 \\
\hline lowland village & $28.3(18.7-35.8)$ & $65.0(36-83)$ & $38,550(2900-95,700)$ & 1 & 2 & 9 & 6 & 18 \\
\hline city town & $25.8(18.8-30.7)$ & $64.0(40-78)$ & $22,000(442-94,000)$ & 0 & 0 & 0 & 0 & 0 \\
\hline
\end{tabular}

* Median (min-max). 
Table 2. Mean number of Chrysomyinae flies collected based on land use types in Chiang Mai province, May 2009-May 2010.

\begin{tabular}{cccccc}
\hline \multirow{2}{*}{ Land Uses } & \multirow{n}{*}{} & \multicolumn{4}{c}{ Fly Species } \\
\cline { 3 - 6 } & & C. pinguis & C. chani & C. villeneuvi $^{\text {Cey. nigripes }}$ \\
\hline mixed deciduous forest & 84 & $4.96 \pm 1.88^{\mathrm{a}}$ & $3.36 \pm 0.91^{\mathrm{a}}$ & $1.94 \pm 0.04^{\mathrm{a}}$ & $1.42 \pm 0.71^{\mathrm{a}}$ \\
disturbed mixed deciduous forest & 34 & 0 & $0.06 \pm 0.04^{\mathrm{b}}$ & $0.06 \pm 0.04^{\mathrm{b}}$ & $0.15 \pm 0.10^{\mathrm{a}}$ \\
mixed orchard & 101 & $0.82 \pm 0.35^{\mathrm{b}}$ & $0.18 \pm 0.07^{\mathrm{b}}$ & $0.27 \pm 0.12^{\mathrm{b}}$ & $0.21 \pm 0.12^{\mathrm{a}}$ \\
paddy field & 34 & $0.32 \pm 0.19^{\mathrm{b}}$ & $1.29 \pm 1.20^{\mathrm{b}}$ & $1.29 \pm 0.90^{\mathrm{a}, \mathrm{b}}$ & $1.24 \pm 1.14^{\mathrm{a}}$ \\
lowland village & 34 & $0.03 \pm 0.03^{\mathrm{b}}$ & $0.06 \pm 0.06^{\mathrm{b}}$ & $0.26 \pm 0.16^{\mathrm{b}}$ & $0.18 \pm 0.08^{\mathrm{a}}$ \\
city town & 15 & 0 & 0 & 0 & 0 \\
\hline
\end{tabular}

Data are presented as mean number $\pm \mathrm{SE} ; n$ a frequency shows the number of observations in each land uses. Different letter $(a, b)$ shown as a significant difference within groups (ANOVA: $p<0.05$ ).

Table 3. Correlation coefficient between the climatic factors and fly populations in the central area of Chiang Mai province, May 2009-May 2010.

\begin{tabular}{cccccc}
\hline \multirow{2}{*}{ Climatic Factors } & \multicolumn{5}{c}{ Fly Species } \\
\cline { 2 - 6 } & & C. pinguis & C. chani & C. villeneuvi & Cey. nigripes \\
\hline temperature & $r$ & $-0.232^{* *}$ & -0.003 & -0.83 & 0.017 \\
& $p$ & 0.000 & 0.961 & 0.148 & 0.768 \\
\hline relative humidity & $r$ & 0.051 & 0.064 & 0.086 & -0.042 \\
& $p$ & 0.374 & 0.266 & 0.138 & 0.462 \\
\hline light intensity & $r$ & $-0.319^{* *}$ & -0.102 & $-0.180^{* *}$ & 0.016 \\
& $p$ & 0.000 & 0.078 & 0.002 & 0.779 \\
\hline
\end{tabular}

The values are presented as Pearson correlation coefficient $(r)\left(P\right.$-sig, two-tailed). ${ }^{*} p=0.05,{ }^{* *} p=0.01$, significant correlations.
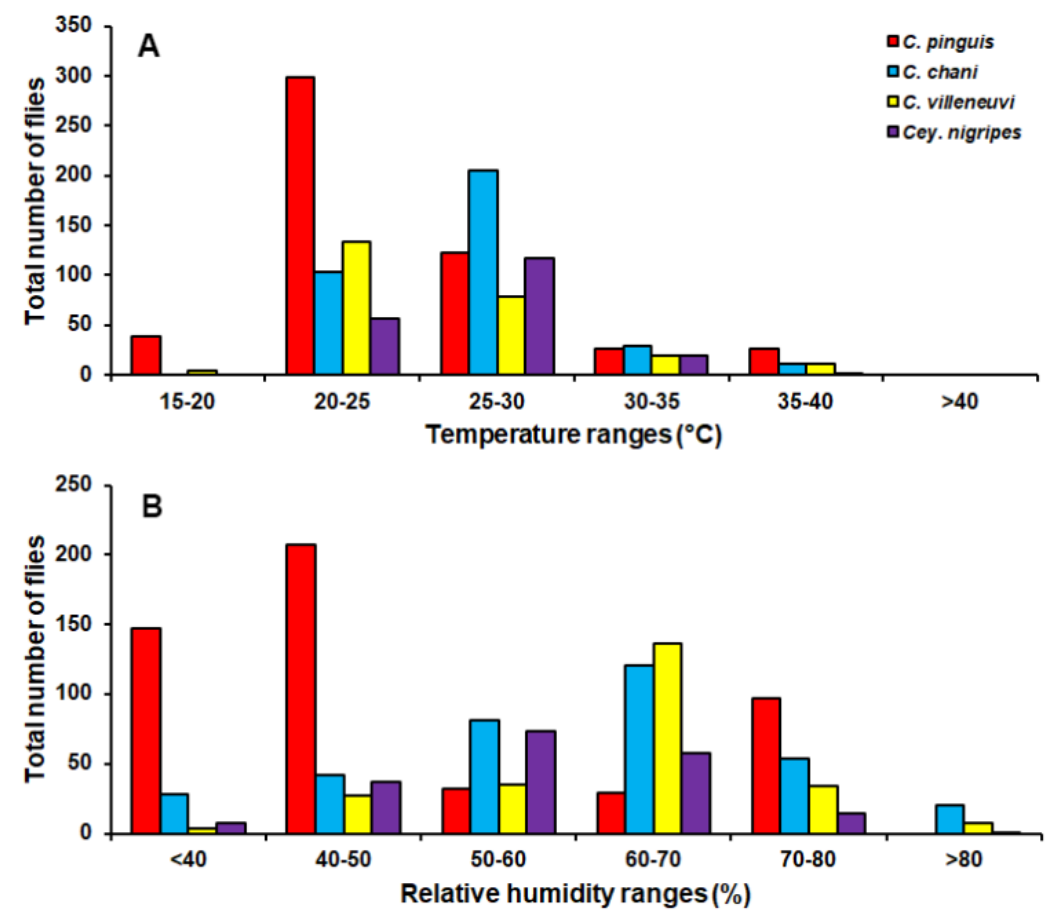

Figure 3. Total number of flies captured at different temperature (A) and relative humidity ranges (B). 


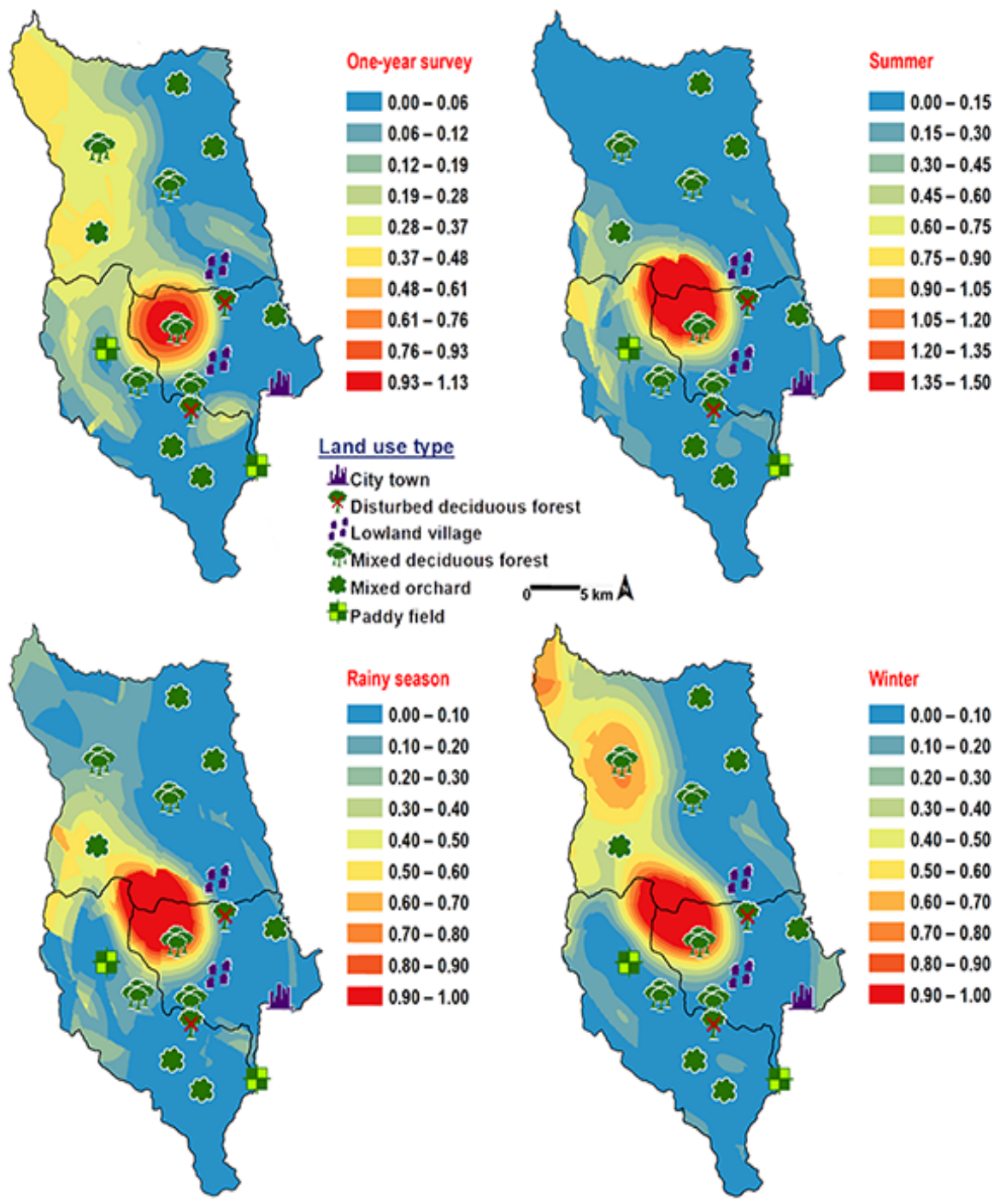

Figure 4. Predictive distribution maps of Chrysomya pinguis. The red areas symbolize the highest density of flies calculated by the analysis, while the blue areas indicate the lowest density. The scale corresponds to the natural logarithm of (fly density +1 ).

Chrysomya chani had quite similar results to that of C. pinguis. This species was prevalent in MDF (Table 2). The abundance of $C$. chani showed no correlation with any climatic factors (Table 3). High number of this species was trapped at $25-30{ }^{\circ} \mathrm{C}$ and $60-70 \%$ RH (Figure 3). A distribution modelling was created using specimens collection data and land use types. According to predicted geographical distribution, this species can probably be found in MDF at $407 \mathrm{~m}$ asl. in Mae Rim district throughout the year. The seasonal prediction maps represented large number of $C$. chani in MDF of mountainous area. Interestingly, in summer this species can probably be found in MDF at $950 \mathrm{~m}$. asl. (MU2) (Figure 5). 


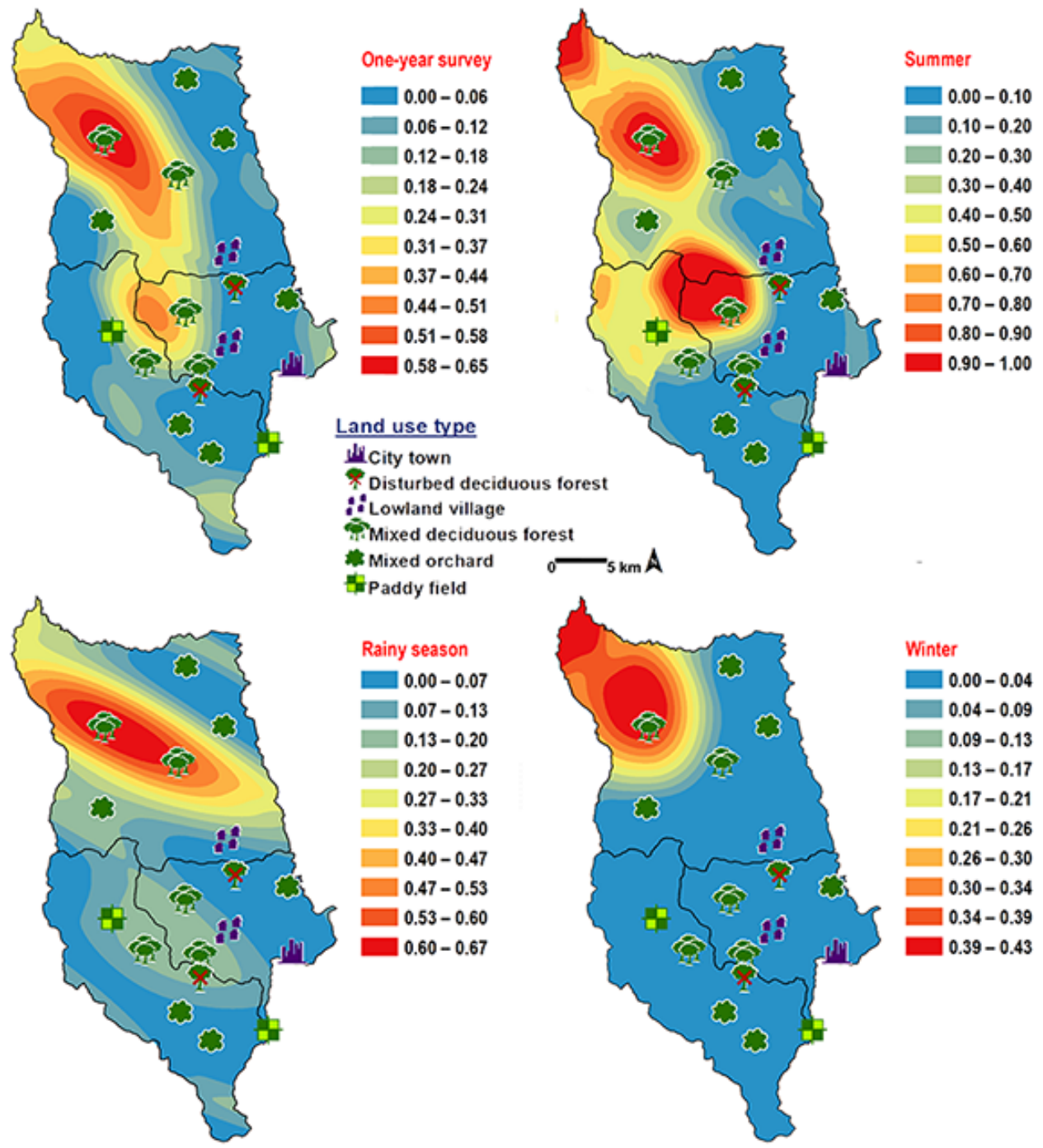

Figure 5. Predictive distribution maps of Chrysomya chani. The red areas symbolize the highest density of flies calculated by the analysis, while the blue areas indicate the lowest density. The scale corresponds to natural logarithm of (fly density +1 ).

Chrysomya villeneuvi was prevalent in MDF and PF (Table 2). The abundance of $C$. villeneuvi showed weak negative correlation with light intensity $(r=-0.180, p=0.002)$ but had no correlation with temperature and relative humidity (Table 3 ). However, high number of this species was collected at $20-25^{\circ} \mathrm{C}$ and $60-70 \% \mathrm{RH}$ (Figure 3). The prediction maps were generated by combining data of fly population, light intensity, and land use types in the analysis. From a year-survey map, the abundance of this species was predicted in MDF at $950 \mathrm{~m}$ asl. (MU2). In summer, the similar pattern to a one-year survey was observed. In rainy season, high number of $C$. villeneuvi was predicted in MO and MDF in mountainous area. In winter, this species was predicted largely in MDF and paddy field (Figure 6). 


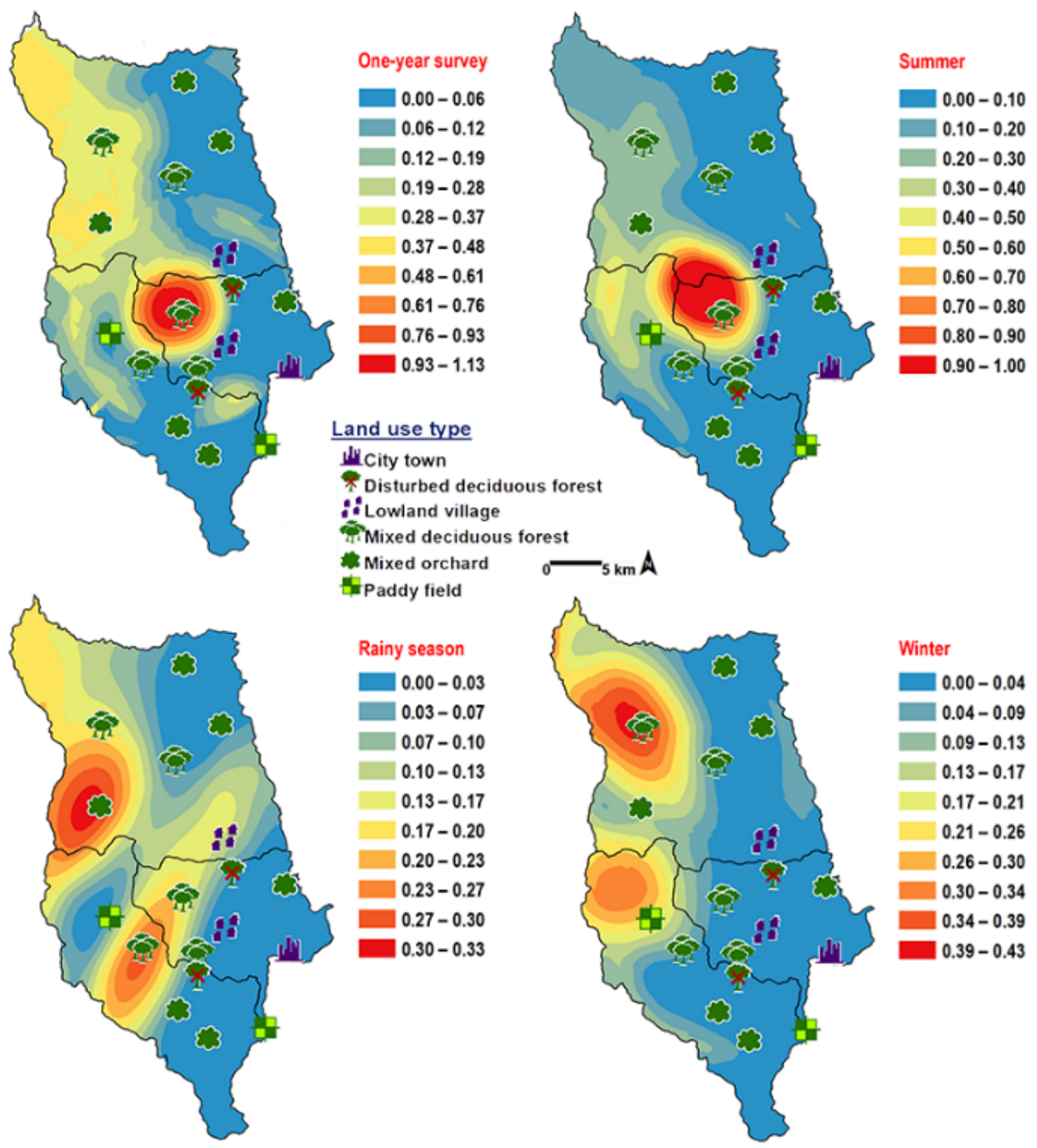

Figure 6. Predictive distribution maps of Chrysomya villeneuvi. The red areas symbolize the highest density of flies calculated by the analysis, while the blue areas indicate the lowest density. The scale corresponds to natural logarithm of (fly density +1 ).

Ceylonomyia nigripes was collected widely in all land uses except for the city (Table 2). No significant relationship was found among the abundance of this species and climatic factors (Table 3). High number of flies was collected at $25-30^{\circ} \mathrm{C}$ and $50-60 \% \mathrm{RH}$ (Figure 3). Fly population data and land uses were applied to create the krigged prediction maps. A one-year survey and summer prediction maps represented similar pattern, as this species was predicted largely in MDF and other land uses along the mountainous area. Low numbers of this species were predicted in the rainy season and in winter (Figure 7). 


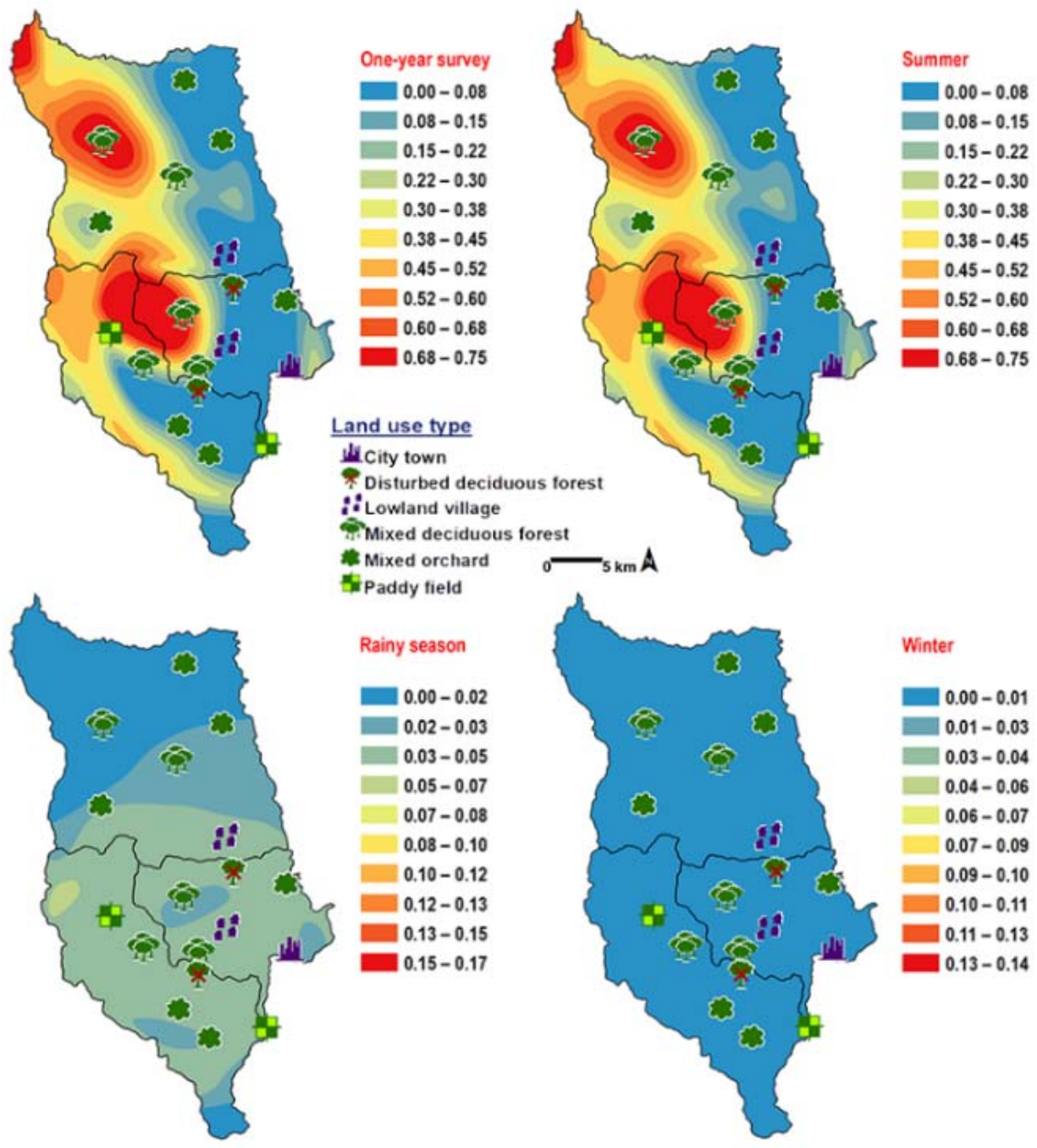

Figure 7. Predictive distribution maps of Ceylonomyia nigripes. The red areas symbolize the highest density of flies calculated by the analysis, while the blue areas indicate the lowest density. The scale corresponds to natural logarithm of (fly density +1 ).

In summary, four species of Chrysomyinae reported here were most abundant in mixed deciduous forest especially in mountainous areas. However, none of these flies were collected in the city town. Although high numbers were collected in the summer months, variations in fluctuation patterns were dependent upon flies' species. Climatic factors showed different impact on flies' population. Nonetheless, none of these flies was collected when the temperature was $>40{ }^{\circ} \mathrm{C}$ (Figure 3).

\section{Discussion}

As previously stated, an adequate knowledge of ecology and geographical abundance of blow flies has a direct application in forensic science [25]. However, the information on geographic distribution of forensically important flies in Thailand is limited. This study was the first to determine the abundance of four forensically important Chrysomyinae flies; C. pinguis, C. chani, C. villeneuvi, and Cey. nigripes, over a full year in northern Thailand. Additionally, predictive distribution maps of these species were generated using systematic random sampling and GIS. Although the collection sites in this study were chosen in different broad ecological locations, our results clearly indicate these four species prefer mixed deciduous forest over the residential areas (e.g., city town and lowland village). This is consistent with the previous study, in which C. chani and Cey. nigripes were collected mostly from corpses found in the forest [19]. A recent study also documented C. pinguis and C. villeneuvi associated 
with a human corpse found in forest of high mountainous area (1200 $\mathrm{m}$ asl.) in northern Thailand [26]. However, C. villeneuvi was also reported in a case from urban/suburban area [19]. In Australia, Cey. nigripes was strongly associated with areas of high percentage of forest cover [27]. On the contrary, the study in Malaysia reported Cey. nigripes on the remains found in a house/apartment [20]. Therefore, the variation of fly infestations in each locality could be due to the availability of food sources, food preferences, ecological features of each locality, and the disturbances of humans.

Local availability of food sources could possibly be the factor affecting the abundance of blow flies found in each land use. In natural conditions, blow flies are typically necrophagous and saprophagous. As bacteria decompose, the necrophagous flies feed on removing the soft tissues of animal carcasses [28]. These four species might prefer small to large wild animal carcasses available in forest areas rather than the garbage or small carcasses, which may be the main resources in nearby residential areas. Furthermore, ecological features in each land uses probably affected ambient temperature as a result of differences in exposure of sunlight. The degree of sun exposure was influenced by the denseness of the trees, the increases in tree cover as in the forest increase sun protection that maintains the temperature range [29]. The study in Malaysia reported a greater variation in weather data recorded in the rural area than in the forest [30]. Furthermore, fewer disturbances from humans in mixed deciduous forests might be another factor affecting these flies' abundance. As reported in Japan, C. pinguis larvae were more likely to be found on corpses found in the less populated areas [17].

Seasonal variation impacted the abundance of blow flies. When individual species were examined in different habitats across seasons, we determined that the abundance and distribution of the fly species in question were impacted. According to our study, blow fly abundance peaked during summer, and diminished in the rainy season and winter. In general, this finding is consistent with previous reports, as greater numbers of flies were found in hot weather season $\left(23-45.2{ }^{\circ} \mathrm{C}\right)$ than in cold weather season $\left(16.7-34.9^{\circ} \mathrm{C}\right)[3,25,31]$. The higher temperatures in the summer period accelerate the developmental rate of blow flies. Conversely, the lower temperatures $\left(16.7-20{ }^{\circ} \mathrm{C}\right)$ in cold weather conditions reduce the attractiveness of the baited trap [32] and the flying activity of flies (Figure 3). Our results further indicate only C. pinguis and C. villeneuvi were active throughout the year. However, it should be noted that these two species were trapped mostly at temperatures from $20-25{ }^{\circ} \mathrm{C}$. The reduction in $\mathrm{C}$. chani and Cey. nigripes numbers during the rainy season and/or winter most likely is due to their preference for higher temperatures $\left(25-30^{\circ} \mathrm{C}\right)$. A study in China also suggested Cey. nigripes prefers warmer temperatures [33]. However, conflicting results were observed by Moophayak et al. [13], when Cey. nigripes only vanished from the summer collections. This may be due to differences in study designs (e.g., sampling method, collection period, and study sites) or population variation [34]. Furthermore, the attractiveness of 1-day tainted bait used in this study may not be suitable for luring C. chani and Cey. nigripes, as they prefer an advanced state of decomposition $[35,36]$. Especially during the rainy season and the winter, volatiles released by the bait most likely decreased thus reducing attraction of flies.

Environmental factors undoubtedly impacted the diversity of blow flies, however, differences were observed among the species. Assessment of climatic factors on fly populations indicated C. pinguis increased when temperature $\left(20.7-23.4{ }^{\circ} \mathrm{C}\right)$ and light intensity (630-1870 lux) were low. A previous laboratory study indicated $C$. pinguis was more active at $15^{\circ} \mathrm{C}$, which supports its preference of the areas and seasons with low temperature [37]. Light intensity also had a negative effect on the population of $C$. villeneuvi. These may support the habitat preferences of these two species, because a mixed deciduous forest has a dense tree cover that protects from the sun and maintain temperature. According to the statistical analysis, C. chani and Cey. nigripes showed no correlation with any climatic factors. Furthermore, humidity has no influence on any species in this study. Azevedo and Krüger [38] reported Chrysomya spp. have a positive correlation with temperature; humidity was determined not to be a factor. Our results clearly indicate that flies are not active when temperature exceeds $40^{\circ} \mathrm{C}$. Similar results were determined for C. rufifacies in Texas, USA with flies not being active during the hottest period of the day [39]. Because blow flies are ectotherm, the temperature is a major factor limiting their environmental preferences [21]. A study in Taiwan also 
reported that a significantly lower eclosion ratio of C. pinguis than C. megacephala at $30^{\circ} \mathrm{C}$ indicated differences between temperature adaptations [37]. Therefore, temperatures $>40{ }^{\circ} \mathrm{C}$ may be too high for these forest-associated species to be adapted. However, it should be emphasized that climatic factors (e.g., temperature, relative humidity and light intensity) in this study were recorded as point data collection at the onset of fly trap setting. Therefore, using climate data logger to record data over the study period may provide a more accurate relationship of environmental factors on fly population dynamics.

The species distribution modelling can identify the preference of a particular species in a certain locality. Therefore, it could be applied to verify the potential of corpse relocation in a forensic scenario [40]. Human remains are more likely to be moved from an open area to a forest habitat because it is more easily to be concealed. As a result, the insects which inhabit a corpse in an open environment but not in forested habitats might be good indicators of remains being relocated [41]. Our results clearly indicated these four Chrysomyinae species prefer mixed deciduous forests over the residential areas (e.g., city town and lowland village). Consequently, these four species might not be suitable indicators for corpse relocation when compare with the common blow flies, C. megacephala and C. rufifacies $[15,16]$. However, the maggots of theses flies can be used in the estimation of $\mathrm{PMI}_{\mathrm{min}}$ when corpses are found in the forest. This study was carried out in only one urban area (Mueang Chiang Mai district). Therefore, the absence of a particular species in a specific habitat does not make it unsuitable to be used as an insect evidence to explain the circumstances associated to death.

During the early postmortem period, the $\mathrm{PMI}_{\text {min }}$ estimation was calculated based on the evaluation of the presumed oldest maggot found on the corpses. As developmental time is species specific, proper identification of the larvae found on a corpse is crucial for accuracy in age estimation [4]. Although larval morphology of these four Chrysomyinae has been well studied, they share some common features making identification difficult (e.g., C. megacephala and C. rufifacies) [26,42-44]. Even though, DNA-based techniques can be used for species identification, there are some limitations. For instance, the molecular approach relied on mitochondrial genes were unable to differentiate C. pinguis and C. megacephala [45]. In India, C. chani and C. megacephala were unable to be distinguished using the COI gene [46]. Our results clarified the distribution ranges of $C$. pinguis and $C$. chani, which are different from $C$. megacephala [16]. Thus, when corpses were found in mixed deciduous forest in mountainous area in Thailand, four Chrysomyinae flies reported here are the major species that should be taken into account.

\section{Conclusions}

This study provides greater detail of the distribution of four carrion-associated species and the factors influencing their distribution. This research generates a better understanding of the distribution of these forensically important fly species in Thailand. Nonetheless, further studies on biological aspects (e.g., biology, life table, insect succession) of these species associated to different land uses, are necessary to gain better understanding on the potential of these species as entomological evidence in forensic investigations.

Author Contributions: Conceptualization, K.S. and K.L.S.; Methodology, K.S., K.N.I., R.N., K.M. and T.K.; Formal Analysis, T.K.; Investigation, K.M., R.N., and T.K.; Resources, K.N.I. and H.K.; Data Curation, T.K. and R.N.; Writing-Original Draft Preparation, T.K.; Writing-Review \& Editing, K.L.S. and J.K.T.; Visualization, T.K.; Supervision, K.S. and K.L.S.; Project Administration, K.S. and K.L.S.; Funding Acquisition, T.C., K.L.S., and K.S.

Funding: We are very grateful to the financial support by the Royal Golden Jubilee Ph.D. Program (PHD/0246/2550 to KLS and TK), Thailand Research Fund (RSA5580010 to KLS; IRN58W0003 to TC, KLS, TK), "Diamond Research Grant" (PAR-2560-04663) of the Faculty of Medicine, Chiang Mai University (to KLS, KS, PS), and Chiang Mai University (CMU) through the Excellence Center for Insect Vector Study (to KLS, PS).

Acknowledgments: We acknowledge the geographic data provider; Department of Geography, Faculty of Social Science, CMU and Geo-Informatics and Space Technology Development Agency, Northern Region, Thailand.

Conflicts of Interest: The authors declare no conflict of interest. The funders had no role in the design of the study; in the collection, analyses, or interpretation of data; in the writing of the manuscript, and in the decision to publish the results. 


\section{References}

1. Tomberlin, J.K.; Crippen, T.L.; Tarone, A.M.; Chaudhury, M.F.B.; Singh, B.; Cammack, J.A.; Meisel, R.P. A review of bacterial interactions with blow flies (Diptera: Calliphoridae) of Medical, Veterinary, and Forensic importance. Ann. Entomol. Soc. Am. 2017, 110, 19-36. [CrossRef]

2. Norris, K.R. The bionomics of blow flies. Annu. Rev. Entomol. 1965, 10, 47-68. [CrossRef]

3. Brundage, A.; Bros, S.; Honda, J.Y. Seasonal and habitat abundance and distribution of some forensically important blow flies (Diptera: Calliphoridae) in Central California. Forensic Sci. Int. 2011, 212, 115-120. [CrossRef] [PubMed]

4. Amendt, J.; Campobasso, C.P.; Gaudry, E.; Reiter, C.; LeBlanc, H.N.; Hall, M.J. Best practice in Forensic Entomology—Standards and guidelines. Int. J. Legal Med. 2007, 121, 90-104. [CrossRef] [PubMed]

5. De Souza, M.S.; Pepinelli, M.; de Almeida, E.C.; Ochoa-Quintero, J.M.; Roque, F.O. Blow flies from forest fragments embedded in different land uses: Implications for selecting indicators in Forensic Entomology. J. Forensic Sci. 2016, 61, 93-98. [CrossRef] [PubMed]

6. Sanit, S.; Sukontason, K.; Kurahashi, H.; Tomberlin, J.K.; Wannasan, A.; Kraisittipanit, R.; Sukontason, K.L. Morphology of immature stages of blow fly, Lucilia sinensis Aubertin (Diptera: Calliphoridae), a potential species of forensic importance. Acta Trop. 2017, 176, 395-401. [CrossRef] [PubMed]

7. Sontigun, N.; Sanit, S.; Wannasan, A.; Sukontason, K.; Amendt, J.; Yasanga, T.; Sukontason, K.L. Ultrastructure of male genitalia of blow flies (Diptera: Calliphoridae) of forensic importance. Acta Trop. 2018, 179, 61-80. [CrossRef] [PubMed]

8. Zajac, B.K.; Sontigun, N.; Wannasan, A.; Verhoff, M.A.; Sukontason, K.; Amendt, J.; Zehner, R. Application of DNA barcoding for identifying forensically relevant Diptera from northern Thailand. Parasitol. Res. 2016, 115, 2307-2320. [CrossRef] [PubMed]

9. Bunchu, N.; Thaipakdee, C.; Vitta, A.; Sanit, S.; Sukontason, K.; Sukontason, K.L. Morphology and developmental rate of the blow fly, Hemipyrellia ligurriens (Diptera: Calliphoridae): Forensic Entomology applications. J. Parasitol. Res. 2012. [CrossRef] [PubMed]

10. Sukontason, K.; Piangjai, S.; Siriwattanarungsee, S.; Sukontason, K.L. Morphology and developmental rate of blowflies Chrysomya megacephala and Chrysomya rufifacies in Thailand: Application in Forensic Entomology. Parasitol. Res. 2008, 102, 1207-1216. [CrossRef] [PubMed]

11. Vitta, A.; Pumidonming, W.; Tangchaisuriya, U.; Poodendean, C.; Nateeworanart, S. A preliminary study on insects associated with pig (Sus scrofa) carcasses in Phitsanulok, northern Thailand. Trop. Biomed. 2007, 24, $1-5$.

12. Moophayak, K.; Sukontason, K.L.; Ruankham, W.; Tomberlin, J.K.; Bunchu, N. Variation in the time of colonization of broiler carcasses by carrion flies in Nakhonsawan Province, Thailand. J. Med. Entomol. 2017, 54, 1157-1166. [CrossRef] [PubMed]

13. Moophayak, K.; Klong-klaew, T.; Sukontason, K.; Kurahashi, H.; Tomberlin, J.K.; Sukontason, K.L. Species composition of carrion blow flies in northern Thailand: Altitude appraisal. Rev. Inst. Med. Trop. Sao Paulo 2014, 56, 179-182. [CrossRef] [PubMed]

14. Sukontason, K.; Sukontason, K.L.; Piangjai, S.; Tippanun, J.; Lertthamnongtham, S.; Vogtsberger, R.C.; Olson, J.K. Survey of forensically-relevant fly species in Chiang Mai, Northern Thailand. J. Vector Ecol. 2003, 28, 135-138. [PubMed]

15. Klong-klaew, T.; Sukontason, K.; Ngoen-klan, R.; Moophayak, K.; Irvine, K.N.; Kurahashi, H.; Prangkio, C.; Sanit, S.; Sukontason, K.L. Impact of abiotic factor changes in blowfly, Achoetandrus rufifacies (Diptera: Calliphoridae), in northern Thailand. Parasitol. Res. 2014, 113, 1353-1360. [CrossRef] [PubMed]

16. Ngoen-klan, R.; Moophayak, K.; Klong-klaew, T.; Irvine, K.N.; Sukontason, K.L.; Prangkio, C.; Somboon, P.; Sukontason, K. Do climatic and physical factors affect populations of the blow fly Chrysomya megacephala and house fly Musca domestica? Parasitol. Res. 2011, 109, 1279-1292. [CrossRef] [PubMed]

17. Toukairin, Y.; Arai, T.; Hoshi, T.; Oliva Trejo, J.A.; Nogami, M. The geographical distribution of fly larvae on corpses in Saitama Prefecture in Japan during the summer season. Leg. Med. 2017, 24, 75-77. [CrossRef] [PubMed]

18. Kavitha, R.; Nazni, W.A.; Tan, T.C.; Lee, H.L.; Azirun, M.S. Review of forensically important entomological specimens collected from human cadavers in Malaysia (2005-2010). J. Forensic Leg. Med. 2013, 20, 480-482. [CrossRef] [PubMed] 
19. Sukontason, K.; Narongchai, P.; Kanchai, C.; Vichairat, K.; Sribanditmongkol, P.; Bhoopat, T.; Kurahashi, H.; Chockjamsai, M.; Piangjai, S.; Bunchu, N.; et al. Forensic Entomology cases in Thailand: A review of cases from 2000 to 2006. Parasitol. Res. 2007, 101, 1417-1423. [CrossRef] [PubMed]

20. Syamsa, R.A.; Omar, B.; Ahmad, F.M.; Hidayatulfathi, O.; Shahrom, A.W. Comparative fly species composition on indoor and outdoor forensic cases in Malaysia. J. Forensic Leg. Med. 2017, 45, 41-46. [CrossRef] [PubMed]

21. Richards, C.S.; Price, B.W.; Villet, M.H. Thermal ecophysiology of seven carrion-feeding blowflies in Southern Africa. Entomol. Exp. Appl. 2009, 131, 11-19. [CrossRef]

22. Rogers, D.J.; Williams, B.G. Monitoring trypanosomiasis in space and time. Parasitology 1993, 106 (Suppl. S1), S77-S92. [CrossRef]

23. Bunchu, N.; Sukontason, K.L.; Olson, J.K.; Kurahashi, H.; Sukontason, K. Behavioral responses of Chrysomya megacephala to natural products. Parasitol. Res. 2008, 102, 419-429. [CrossRef] [PubMed]

24. Tumrasvin, W.; Kurahashi, H.; Kano, R. Studies on medically important flies in Thailand VII. Report on 42 species of Calliphorid flies, including the taxonomic keys (Diptera: Calliphoridae). Bull. Tokyo Med. Dent. Univ. 1979, 26, 243-272. [PubMed]

25. Zabala, J.; Diaz, B.; Salona-Bordas, M.I. Seasonal blowfly distribution and abundance in fragmented landscapes. Is it useful in forensic inference about where a corpse has been decaying? PLoS ONE 2014, 9, e99668. [CrossRef] [PubMed]

26. Monum, T.; Sukontason, K.L.; Sribanditmongkol, P.; Sukontason, K.; Samerjai, C.; Limsopatham, K.; Suwannayod, S.; Klong-klaew, T.; Wannasan, A. Forensically important blow flies Chrysomya pinguis, C. villeneuvi, and Lucilia porphyrina (Diptera: Calliphoridae) in a case of human remains in Thailand. Korean J. Parasitol. 2017, 55, 71-76. [CrossRef] [PubMed]

27. Kavazos, C.R.J.; Wallman, J.F. Community composition of carrion-breeding blowflies (Diptera: Calliphoridae) along an urban gradient in south-eastern Australia. Landsc. Urban Plan. 2012, 106, 183-190. [CrossRef]

28. Baumgartner, D.L.; Greenberg, B. Distribution and medical ecology of the blow flies (Diptera: Calliphoridae) of Peru. Ann. Entomol. Soc. Am. 1985, 78, 565-587. [CrossRef]

29. Grant, R.H.; Heisler, G.M.; Gao, W. Estimation of pedestrian level UV exposure under trees. Photochem. Photobiol. 2002, 75, 369-376. [CrossRef]

30. Silahuddin, S.A.; Latif, B.; Kurahashi, H.; Heo, C.C. The importance of habitat in the ecology of decomposition on rabbit carcasses in Malaysia: Implications in Forensic Entomology. J. Med. Entomol. 2015, 52, 9-23. [CrossRef] [PubMed]

31. Weidner, L.M.; Jennings, D.E.; Tomberlin, J.K.; Hamilton, G.C. Seasonal and geographic variation in biodiversity of forensically important blow flies (Diptera: Calliphoridae) in New Jersey, USA. J. Med. Entomol. 2015, 52, 937-946. [CrossRef] [PubMed]

32. Hwang, C.; Turner, B.D. Spatial and temporal variability of necrophagous Diptera from urban to rural areas. Med. Vet. Entomol. 2005, 19, 379-391. [CrossRef] [PubMed]

33. Li, L.; Wang, Y.; Wang, J.; Ma, M.; Lai, Y. Tempeature-dependent development and the significance for estimating postmortem interval of Chrysomya nigripes Aubertin, a new forensically important species in China. Int. J. Legal Med. 2016, 130, 1363-1370. [CrossRef] [PubMed]

34. Owings, C.G.; Spiegelman, C.; Tarone, A.M.; Tomberlin, J.K. Developmental variation among Cochliomyia macellaria Fabricius (Diptera: Calliphoridae) populations from three ecoregions of Texas, USA. Int. J. Legal Med. 2014, 128, 709-717. [CrossRef] [PubMed]

35. O'Flynn, M.A. Notes on the biology of Chrysomya nigripes Aubertin (Diptera: Calliphoridae). Aust. Entomol. 1983, 22, 341-342. [CrossRef]

36. Ahmad, N.W.; Lim, L.H.; Dhang, C.C.; Chin, H.C.; Abdullah, A.G.; Mustaffa, W.-N.W.; Kian, C.W.; Jeffery, J.; Hashim, R.; Azirun, S.M. Comparative insect fauna succession on indoor and outdoor monkey carrions in a semi-forested area in Malaysia. Asian Pac. J. Trop. Biomed. 2011, 1 (Suppl. S2), S232-S238. [CrossRef]

37. Yang, S.T.; Shiao, S.F. Temperature adaptation in Chrysomya megacephala and Chrysomya pinguis, two blow fly species of forensic significance. Entomol. Exp. Appl. 2014, 152, 100-107. [CrossRef]

38. Azevedo, R.R.; Krüger, R.F. The influence of temperature and humidity on abundance and richness of Calliphoridae (Diptera). Iheringia Sér. Zool. 2013, 103, 145-152. [CrossRef]

39. Mohr, R.M.; Tomberlin, J.K. Environmental factors affecting early carcass attendance by four species of blow flies (Diptera: Calliphoridae) in Texas. J. Med. Entomol. 2014, 51, 702-708. [CrossRef] [PubMed] 
40. Charabidze, D.; Gosselin, M.; Hedouin, V. Use of necrophagous insects as evidence of cadaver relocation: Myth or reality? PeerJ 2017, 5, e3506. [CrossRef] [PubMed]

41. Matuszewski, S.; Szafalowicz, M.; Jarmusz, M. Insects colonising carcasses in open and forest habitats of Central Europe: Search for indicators of corpse relocation. Forensic Sci. Int. 2013, 231, 234-239. [CrossRef] [PubMed]

42. Sukontason, K.L.; Vogtsberger, R.C.; Boonchu, N.; Chaiwong, T.; Sripakdee, D.; Ngern-Klun, R.; Piangjai, S.; Sukontason, K. Larval morphology of Chrysomya nigripes (Diptera: Calliphoridae), a fly species of forensic importance. J. Med. Entomol. 2005, 42, 233-240. [CrossRef] [PubMed]

43. Sukontason, K.L.; Bhoopat, T.; Wannasan, A.; Sontigun, N.; Sanit, S.; Amendt, J.; Samerjai, C.; Sukontason, K. Chrysomya chani Kurahashi (Diptera: Calliphoridae), a blow fly species of forensic importance: Morphological characters of the third larval instar and a case report from Thailand. Forensic Sci. Res. 2018, 3, 83-93. [CrossRef]

44. Sukontason, K.; Sukontason, K.L.; Piangjai, S.; Narongchai, P.; Samai, W.; Boonchu, N.; Sripakdee, D.; Ngern-Klun, R.; Siriwattanarungsee, S. Morphology of second and third instars of Chrysomya villeneuvi Patton (Diptera: Calliphoridae), a fly species of forensic importance. Forensic Sci. Int. 2005, 154, 195-199. [CrossRef] [PubMed]

45. Kavitha, R.; Nazni, W.A.; Tan, T.C.; Lee, H.L.; Isa, M.N.; Azirun, M.S. Molecular identification of blow flies recovered from human cadavers during crime scene investigations in Malaysia. Malays. J. Pathol. 2012, 34, 127-132. [PubMed]

46. Bharti, M.; Singh, B. DNA-based identification of forensically important blow flies (Diptera: Calliphoridae) from India. J. Med. Entomol. 2017, 54, 1151-1156. [CrossRef] [PubMed]

(C) 2018 by the authors. Licensee MDPI, Basel, Switzerland. This article is an open access article distributed under the terms and conditions of the Creative Commons Attribution (CC BY) license (http:/ / creativecommons.org/licenses/by/4.0/). 